covering that the present drainage system began to be traced, and the channels originally chosen by the streams that first flowed over it still, on the whole, keep to the same courses, though they have now cut their way down into the older rocks. The most helpful line of investigation that can at present be pursued in this subject is to be found in the search for actual or probable evidence of the extent of the denuded formations. The recent discovery by the Geological Survey of masses of Rhætic, Liassic and Chalk strata in a Tertiary volcanic vent in the Isle of Arran, which proves the former extension of these formations into the west of Scotland, is an example of the unexpected way in which the most important evidence may at any moment be discovered. But even if no such evidence should be forthcoming, it is impossible to contemplate the prodigious denudation of the country even among solid massive rocks like the lavas of the west of Scotland without the profound conviction that since Tertiary time hundreds of feet of rock have been removed from the surface, and that it is impossible to comprehend the history of our landscapes without taking this momentous fact into account.

\section{THE ROYAL SOCIETY AND THE PROPOSED BRITISH ACADEMY.}

THE following letter on this subject appeared in the Times of March 20 :-

To the Editor of the TIMES.

SIR,--In the references which have been recently made to the early history of the Royal Society, the charters of King Charles II. have frequently been remarked upon, and also the subject-matter of the communications published by the Philosophical Transactions from time to time. It has been conceded by many who have given attention to the matter that the charters of King Charles II. intended that the then newly-founded Society should take cognisance, not only of observational and experimental science, but also of those philosophical, historical and philological subjects for which, on the ground that they lack representation to-day, King Edward VII. has been petitioned to grant a charter enabling some new body to look after their interests. It has also been conceded that the early practice of the Royal Society was in accordance with the suggested intention referred to above, so far as the communications made to it enable us to form a judgment.

In a previous letter on this subject, which you were good enough to insert in the Times of January 29, I pointed out that a committee specially appointed by the Council of the Royal Society to consider the matter had reported, after consultation with high legal authorities, that the inclusion of the subjects within the scope of the Royal Society, for the general organisation of which it is now proposed to found a new Academy, is within the powers conferred on it by the charters of that Society. I venture to give two extracts from the first charter granted by King Charles II. which alone seem to establish this conclusion. If you will permit me, I will reproduce them here :-

Charles II., by the grace of God King of England, Scotland, France and Ireland, Defender of the Faith, \&c., to all to whom these present Letters shall come, greeting.

We have long and fully resolved with Ourself to extend not only the boundaries of the Empire, but also the very arts and sciences. Therefore we look with favour upon all forms of learning, but with particular grace we encourage philosophical studies, especially those which by actual experiment attempt either to shape out a new philosophy or to perfect the old. In order, therefore, that such studies, which have not hitherto been sufficiently brilliant in any part of the world, may shine conspicuously amongst our people, and that at length the whole world of letters may always recognise us not only as the Defender of the Faith, but also as the universal lover and patron of every kind of truth: Know ye, \&c.

$$
\text { No. I691, vOL. 65] }
$$

Of the "Fellows" it is written:-

The more eminently they are distinguished for the study of every kind of learning and good letters, the more ardently they desire to promote the honour, studies and advantage of this Society . . . the more we wish them to be especially deemed fitting and worthy of being admitted into the number of the Fellows of the same Society.

Of course it would have been very much more satisfactory if the committee, instead of enunciating pious and legal opinions as to what the charters enabled the Society to do, as abstractedly as if the Society had never existed, had; seeing that action under the charters had been going on for nearly two centuries and a half, told us what the Society had really done year after year in the matter of choosing men for election into the Society. In this way sure proof could be obtained of the general opinion of what the charters empowered and enjoined the Society to do, not only at the time they were conferred, but at subsequent dates. This course, which obviously is the only satisfactory way of arriving at a conclusion on the questions at issue, was, however, not open to the committee ; for a complete list of the officers, Fellows and foreign members elected in each year from the foundation of the Society was not generally available.

This gap in our knowledge of the actual life of the Society has recently been filled, and we can now learn the kind of work for which the Society considered itself responsible by the men it elected to do it in its early days, and especially by those who were elected to fill the various offices. It will be obvious that a complete inquiry of this nature is a matter involving considerable time and labour; but in the present state of the question raised by the proposition for a new British Academy it is of such high importance to know the facts that I have not hesitated to try to get at them, however imperfectly ; my inquiry being limited as much as possible, this has been done by passing over all doubtful cases and considering chiefly the first century of the life of the Society, that is from 1663 .

The general result of this limited inquiry may be stated as follows :--

I begin with the presidents. Some were appointed on account of their rank, others on account of their contributions to observational or experimental science, among them Wren, Newton, the Earl of Macclesfield, and others. But besides these we have Sir John Hoskins, "a most learned virtuoso as well as a lawyer," according to Evelyn ; Samuel Pepys, of diary fame; Martin Folkes, an antiquarian "under whom the meetings were more literary than scientific"; Sir James Burrow, an antiquarian, also a lawyer ; and James West, another antiquarian and collector of coins, and given to "black letter lore." If we pass the first century, we find Sir John Pringle, a learned physician and professor of metaphysics and moral philosophy, elected in 1772 , and Davies Gilbert in $\mathbf{1} 827$, who, although addicted to science, was chiefly an antiquarian and historian.

Among the treasurers we find one of the first appointed Abraham Hill, given as much to moral as to natural philosophy; Roger Gale, an archæologist and numismatist; and, again passing the first century, Wm. Marsden (1802), an Oriental scholar, and Samuel Lysons (i8ro), an antiquarian and an artist.

We next come to the secretaries. The most remark. able thing about these officers is that between 1663 and I765, of the twenty-nine elected no less than sixteen were doctors of divinity, medicine or law; and, so far as the inquiry has gone, the "Dictionary of National Biography "shows that they were not merely professional men, but scholars first and writers afterwards. The secretary elected in 1776 was Joseph Planta, the librarian of the British Museum; while in 18 I2 Humphry Davy was followed by Taylor Combe, an archæologist and numismatist. 
The office of foreign secretary was created in 1723. Of the eight appointed down to 1772 , four were doctors of medicine, and they were selected possibly for the same reason as their colleagues among the secretaries. Maty, who was elected in 1772 , was the assistant librarian in the British Museum.

The enormously wide area of knowledge from which the officers of the Society were drawn during the first century is in sharp antithesis to the narrow ground of award of the Copley medal, which was first conferred in 173I. The grant of this medal is limited to the author of the most important discovery or contribution to science by experiment or otherwise; and the greater the divergence between the officers' and Copley medallists' lists, the less, naturally, was the limitation of the Fellowship to those interested alone in experiment or observation.

We next come to the Fellows of the Society. The following lists are based upon a rapid reconnaissance of those who occur early in the alphabetical order, using Hole's "Brief Biographical Dictionary" as a means of determining their identity. The names of many Fellows are absent from Hole, and there are some incertitudes, besides which Hole's definitions are very terse. The lists, however, are given for what they are worth; and there can be little doubt that they will soon be replaced by complete and authoritative lists officially compiled. It is important that the Lords of the Privy Council should possess such documents to assist them in the important inquiry with which they are charged; and we may hope that this eagerness to possess is only equalled by the anxiety of the Royal Society to provide them if their compilation be in the interests of truth :-

Archaeologists and Anti. quarians.

Ames, Josh............. 1743

Amyot, Thos............ 1824

Ashmole, Elias .......... 1663

Astle, T. ................. I766

Ayloffe, J. ............... I 73 I

Baker, G. ............. I762

Brander, G............... I754

Bridges, J. ............... I 708

Churchill, Winston .... 1664

Gale, R. .............. r 7 I8

Gale, T. ................ 1677

\section{Writers.}

Askew, Ant. …...... 1749

Barrington, Daines...... I 767

Bathurst, Ralph ......... I 1663

Becket, Wm. ............. 1718

Bentley, R............... 1695

Birkenhead, J. ......... I 663

Bowlden, T. ............. I78 I

Brocklesby, R. .......... I 746

Brown, R. ............. I8II

Bruce, J.................... $179 \mathrm{I}$

Burnet, T. ................ 1748

Burney, C. (Music) .. 1773

Cadogan, W. ............ 1752

Chandler, J. ............ I 734

Edgeworth, R. L. ...... I78 I

Egerton, F. H. .......... $\quad$ r78 I

Farmer, R. .............. I 79I

Green, T. …......... 1798

\section{Historians.}

Abel, Clarke ........... I819

Barnes, Joshua ......... I7IO

Beaufort, Louis de ......

Bernard, C............... 1696

Birch, T................... I 734

Clarke, J. G. ........... 1792

Coxe, W.................. I782

Duclos, C. .............. I $\quad$ I 64

Edwards, B. .......... I $\quad$ I794

Ellis, G. A. .......... I816

Gillies, J. …........ I789

Philologists.

Colebrooke, H. T...... 1816

Dickenson, E. $\quad$......... 1677

Poets.

Akenside, Mark........ I 753

Browne, J. H. ......... 1749

Byron, Lord $\ldots \ldots \ldots \ldots . . .18$

Denham ................ I663

Dryden, J. ............... 1663

Ellis, G. .................. 1797

Bruce, James ........... I776

Brydone, P. ........... I773

Carteret, P.............. I664

Chardin, J................ 1682

Lawyers.

Adair, James ........... I7 788

Aland, J. F. .......... 1711

Arden, R. P. ............. 1788

Dalrymple, J........... 1796

Although the matter has not as yet been inquired into, there is already ample evidence that the foreign members were selected with the same catholicity as the ordinary Fellows. Thus Sorbière, an eminent French litterateur, was elected in 1663 (the first year); the Italian historian Gregorio Leti was elected in $168 \mathrm{I}$; and the French historian Michael Le Vassor in I7or.

It does not seem possible that any unprejudiced mind, after a perusal of the above statements, limited though they are to a point of time, and, in the case of the Fellows, to a few letters of the alphabet, and inaccurate as they may well be here and there, can deny that the reconnaissance affords valuable evidence that the action of the Royal Society for the first century after it had received its charters was as broad as the charters themselves. The Society tried to do, and succeeded in doing, the duty which the charters imposed upon it.

We learn from the above statements that for the period over which my hasty inquiry has gone, Britain possessed a general organisation of learning as complete, though not so detailed, as that of the Institute of France or any other foreign academy to-day. King Charles II. had, in fact, in his charters, and the Royal Society had, in fact, in its action upon them, anticipated the work of Napoleon by very nearly a century and a half; the portals of the Royal Society and of the Institute of France were equally wide, and wide enough to admit the most illustrious men produced in each country.

If I have erred in any way in reading the facts or in drawing conclusions from them, I sincerely trust that someone with more leisure and knowledge than I will discover where I have gone wrong and at once put the matter right. I am the more anxious that this should be done because I gather from the petition of the Royal Society Council to King Edward VII., which was printed in the Times of February 27 , that the condition of things which the facts reveal is either unknown to the Council or regarded by them as a matter not worth mentioning.

In that petition $H$ is Majesty is informed that the President and Council are of opinion that the studies which it has been shown were fully provided for by King Charles II,'s charters to the Royal Society, and "taken care of "for, at all events, the first century to which my inquiry was limited, "ought to be taken care of by some academic organisation, and that this should be effected, not by the Royal Society taking charge of these studies, but by the establishment of some other body."

I submit, Sir, that the view that a complete inquiry should be made before any step be taken towards creating a new body to do what the charters of King Charles II. enjoined and empowered the Royal Society to undertake is vastly strengthened by the facts now brought to light, which show us what the Royal Society actually did.

This inquiry was thus referred to in the petition to the King, dated February I 4 , which was signed by many eminent representatives of the intellectual, industrial and other forces of the Kingdom :-

We Your Petitioners humbly pray that Your Majesty may be graciously pleased to cause an inquiry to be made with a view of instituting a general and formal organisation of all the studies depending upon scientific method now carried on similar to that inaugurated for the philosophical studies of the seventeenth century by the charters of His Majesty King Charles II.

$$
\text { I, am, Sir, }
$$

Your obedient servant, NORMAN LOCKYER.

Athenæum Club, March II.

\section{ANNOUNCEMENT OF NEW MAMMALIAN REMAINS FROM EGYPT.}

THE discovery of ancestral Proboscidean and other remarkable mammalian forms in the Egyptian desert has already been noticed in NATURE (vol. 1xiv. p. 582 ). Dr. C. W. Andrews's preliminary descriptions of the remains show that the deposits are of deep interest to palæontologists and other students of mammalian morphology and distribution. Mr. H. J. L. Beadnell now announces, in a pamphlet of two pages of text, illustrated by six plates, that explorations of the desert bounding the

NO. I691, VOL. 65] 